\title{
Tenure Review, Property Rights and Public Policy ${ }^{1}$
}

\author{
Neil Quigley
}

\section{Introduction}

Large tracts of the South Island high country are farmed under leases that are perpetually renewable at the discretion of the lessee. Changes in views about the optimal use of the high country have resulted in the government instituting a tenure review process, under which the Crown is negotiating with the owners of South Island pastoral leases to redefine the property rights associated with those leases. As a result of tenure review, the portions of these pastoral estates that have high conservation and/ or low farming value are being returning to the Crown under management of the Department of Conservation (DOC), while those portions of the estates that have high value in farming or other uses are transferred to the freehold ownership of the former lessee.

In an article published in the last Policy Quarterly, Ann Brower (2007) suggested that tenure review is producing outcomes that are:

- consistent with no-one advocating for the Crown's interest, based on the Crown tacitly agreeing to 'lose' in the negotiation process;

- consistent with officials acting to close the deal at any costs, so that the deals struck strongly resemble the lessees' demand curve for freehold land;

- inconsistent with the relevant law on property rights.

In this paper I first review the tenure review process and the property rights issues associated with this. Second, I provide an analysis of the evidence presented by Brower. Thirdly, I conclude with an alternative view of the key public policy issues and suggest that the tenure review process is a positive one for New Zealand.

\section{Property rights}

A property right provides the right to use resources for certain purposes, and the holder of a property right is the person or group with the ability to exercise the relevant use rights. There is no simple match between allocations of property rights and the concept of ownership as it is used in popular language.

In the case of a perpetually renewable lease, the allocation of property rights makes the concept of ownership extremely complex. These leases limit the range of activities that farmers may undertake on the land, and require that the farmers pay rent to the Crown based on unimproved land values. But in other respects the leases approximate freehold rights to occupy and use the land, exclude others from using the land, and transfer their rights to others. ${ }^{2}$ So, despite the Crown's interest as a lessor, land subject to pastoral lease is not 'public' land; the Crown must negotiate agreed terms if it wishes to review tenure without breaching the legal rights of the lessee.

The lessees hold title to a perpetually renewable leasehold estate, which means that land covered by pastoral leases is not 'public' land that is available for allocation at the discretion of the Crown, but rather land alienated into private hands by the Crown. The fact that the alienation occurred through a perpetually renewable lease rather than a transfer of the fee simple (freehold property rights) does not change the fact that alienation has occurred.

Similarly, it is incorrect to claim that retention by the Crown of the use rights except pastoralism provides the Crown with valuable property rights in pastoral leases. The Crown alienated the ability to exercise those rights when it issued the lease by virtue of providing

1 This paper draws on earlier work with Lewis Evans and my correspondence with Ann Brower and Philip Meguire.

2 In fact there is a market for both lessees' and lessors' interests in perpetually renewable real estate in New Zealand, providing market reference points for valuation (see, for example, Boyle et al., 2008). 
leaseholders with a perpetually renewable right to exclusive occupation and quiet enjoyment of a pastoral estate. ${ }^{3}$ The Crown has no rights to do anything with the land except collect rent and adjudicate on any activities proposed that are not permitted under the lease, unless the lessee chooses to sell their interest in the land to the Crown or not to renew the lease at the point of renewal. In other words, whatever alternative rights the lessor might have are of no value at all unless we can assign a positive probability of a lessee quitting the lease at the time of the review.

\section{Tenure review negotiations}

A key driver of the tenure review policy is the desire of the government to see large parts of the land currently under pastoral lease added to the conservation estate. This is important in two respects. First, it establishes the nature of the demand for the purchase of the lessees' rights by the Crown. Second, it tells us something about the Crown's demand for leasehold rights; the Crown should be prepared to pay any price up to the perceived conservation value obtained by adding the land to the conservation estate.

The economic basis for the negotiation between the lessee and the Crown begins with the fact that the lessee has rights of occupancy in perpetuity, and the Crown must induce the lessee to give up those rights for any land that is returned to the conservation estate. Similarly, for land that will be retained by the lessee in freehold title, the lessee must compensate the Crown for giving up its interest as lessor. In addition, there may be features of the property that provide it with value over and above those anticipated when the pastoral leases were originally drawn up - in particular, value for commercial tourism and for rural-residential lifestyle and privacy. Thus, to understand the values established as part of tenure review we need to ascertain:

- the value of the lessee's interest in the total leasehold area covered by each review;

- the value of the lessor's interest while the land is subject to lease in perpetuity; and

- the value of those features of the land that might impact on its market value but are not part of the asset base on which the rent is set, and a division of that value between lessee and lessor. ${ }^{4}$

Tenure review is a process by which economic assets are transferred from private to public ownership: extinguishing lessees' rights is a process of transferring economic assets from private ownership to the Crown. Since more land subject to pastoral lease is given up than is transferred into freehold land (the difference being the land added to the conservation estate), it would probably be more accurate to describe tenure review as a process of nationalisation than of privatisation.

To illustrate the way in which the tenure review process works, and values payable for the Crown and the lessor are established, I summarise in Table 1 the outcomes from two tenure reviews. Lease \#1 was described by the valuers as a property with low productivity in pastoral farming and limited improvements by the lessee, while Lease \#2 was described as having a high productivity in farming and has substantial improvements put in place by the lessee. Consistent with this, $72.2 \%$ of the land in Lease \# 1 was transferred to DOC, while $27.4 \%$ of the land in Lease \#2 was acquired by the Crown.

The data from these two tenure reviews illustrate two important points in the process. First, valuers employed by the lessee and valuers employed by the Crown assess the market value of the pastoral estates, and apportion this between the lessee and the Crown as lessor (50\% in both cases). Second, in assessing the Crown's interest, two factors are important: the present value of the rental payments, and an apportionment between the two parties of those values that are not counted in the rental value.

The Crown's interest in the land transferring to freehold is generally smaller than in the land transferring to DOC, because the land transferring to freehold will generally have been the focus of lessee improvements that raise its value but do not raise Crown's interest.

The Crown's interest in the poor quality estate is lower because the limited productivity of the estate in pastoralism meant that the rent payable was low on a per hectare basis.

3 A perpetually renewable lease provides the lessee with the option, at each point of renewal, to determine the lease and the flow of rental payments to the Crown, or to acquire the freehold rights should the Crown wish to sell them. While this right to determine the lease may rarely be invoked, it does provide an option to the lessee that is valuable, and would be exercised if ever (for example) the rental payments were set at such a high level as to undermine the economic viability of the permitted activity (pastoral grazing).

4 For a full and very clear description of the valuation approach taken in tenure review see Armstrong et al. (2005). 
Table 1: Comparison of two tenure review outcomes

\begin{tabular}{|c|c|c|c|c|c|c|}
\hline & \multicolumn{3}{|c|}{ Pastoral Lease \#1 } & \multicolumn{3}{|c|}{ Pastoral Lease \#2 } \\
\hline & $\mathrm{Ha}$ & $\begin{array}{l}\text { AMV } \\
\$(000)\end{array}$ & $\%$ & $\mathrm{Ha}$ & $\begin{array}{l}\text { AMV } \\
\$(000)\end{array}$ & $\%$ \\
\hline Land Transferring to D.O.C. & 5278 & 2885 & & 1249 & 1452 & \\
\hline - Lessee's interest & & 2580 & & & 1012 & \\
\hline - Crown's interest & & 305 & 10.6 & & 440 & 30.3 \\
\hline
\end{tabular}

\begin{tabular}{|l|l|l|l|l|l|l|}
\hline Land Transferring to Freehold & 2136 & 1090 & & 3305 & 5598 & \\
\hline - Lessee's interest & & 1015 & & & 4358 & \\
\hline - Crown's interest & & 75 & 6.9 & & 1240 & 22.2 \\
\hline
\end{tabular}

\begin{tabular}{|l|l|l|l|l|l|l|}
\hline Total Capital Value & 7414 & 3975 & & 4554 & 7050 & \\
\hline - Lessee's interest & & 3595 & & & 5370 & \\
\hline - Crown's interest & & 380 & 9.6 & & 1727 & 24.5 \\
\hline
\end{tabular}

\begin{tabular}{|l|l|l|l|l|l|l|}
\hline Reconciling the Crown's Interest & & & & & & \\
\hline - Present value of rent & & 32 & & & 927 & \\
\hline - Crown's interest in non-rentable value & & 348 & & & 800 & \\
\hline
\end{tabular}

The proportion of the Crown's interest in Lease \#1 is much lower because the present value of rental payments is so small. It would have been less than $1 \%$ if not for an apportionment to the Crown of $50 \%$ of the value in non-rentable values.

\section{Defining the Crown's interest}

Brower (2007) presents the results of an analysis of data relating to 77 completed tenure reviews. She does not indicate that the graph presents the result of a regression analysis rather than data drawn directly from the tenure revew documents, and she does not define the Crown's interest. The definition of the dependent variable in her regression is given in Brower, Monks and Mequire (2007) as $C I=P_{L} /\left(P_{L}+P_{C}\right)$, where $P_{L}$ is the price per hectare received by the Crown for the land acquired by the lessee as freehold and $P_{C}$ is the price per hectare received by the lessee for the land acquired by the Crown.
To illustrate the problem, consider a simple numerical example: if the per hectare value of the freehold land acquired by the lessee is $\$ 1,000$ and the per hectare value of the land acquired by the Crown is $\$ 500$, then $P_{L} /\left(P_{L}\right.$ $\left.+P_{C}\right)=\$ 1,000 / \$ 1,500=0.67$. The interpretation of the numerator, $P_{L}$, is clear, but what interpretation can be placed on the denominator $\$ 1,500$ ? It is the sum of two values per hectare, but what does that mean in economic terms? The lessee and the Crown acquire different types of land, suitable for different uses, and with different values in those different uses. What concept is captured by adding those two per-hectare values together, and how does this relate to the Crown's interest?

With some algebraic manipulation, it is possible to show that the inverse relationship between the Crown's interest and the percentage of the lease transferred to freehold in Brower's analysis reflects the fact that in many tenure reviews the value of the required payment to the Crown was around $70 \%$ of the value of the 
Table 2: Comparison of two definitions of the Crown's interest

\begin{tabular}{|l|l|l|}
\cline { 2 - 4 } \multicolumn{1}{c|}{} & Pastoral Lease \#1 & Pastoral Lease \#2 \\
\cline { 2 - 4 } \multicolumn{1}{c|}{} & $\%$ & $\%$ \\
\hline Tenure Review Valuations & & 24.5 \\
\hline Crown's interest (from Table 1) & 9.6 & \\
\hline $\begin{array}{l}\text { Brower's Definition } \\
P_{L} /\left(P_{L}+P_{C}\right) \text { (from data in Table 1) }\end{array}$ & 6.6 & 31.7 \\
\hline
\end{tabular}

required payment to the lessee for land acquired by DOC. ${ }^{5}$ Given the concentration of lessee improvements on the land transferred to freehold and thus the lower percentage of the Crown's interest in the total value of that land, this is hardly surprising.

To consider the implications of Brower's definition of the Crown's interest, Table 2 compares her definition with the calculation of the Crown's interest drawn from the agreed valuations in each tenure review. As can be seen, Brower's method produces a definition of the Crown's interest that is materially different from the actual proportion of the capital value attributed to the Crown in the tenure review outcomes for the leases considered here.

As an indication of the benefits that might come from a qualitative analysis of the actual valuations determined in tenure review, consider the 'dots' (as Brower calls them) at the bottom right of her Figure 4. These suggest that in some transactions, $100 \%$ of the leasehold land was retained by the lessee, but that the Crown's interest was assessed to be zero. Since these data relate to just three individual tenure review transactions, and since the data in the reviews are publicly available and readily interpreted, why does Brower not provide some more detailed analysis of those individual transactions to inform the reader of the circumstances in which this result occurred and to convince us that the results of her data analysis are actually meaningful?

5 My proof of this proposition is not reproduced here, but has been provided to Brower and Meguire, and is available to readers of this article on request.

\section{Conclusion}

The public naturally has an interest in tenure review since it is motivated by the fact that alternative and multiple uses of the land, rights of access for recreation, and permanent restoration to conservation estate now assume much more importance for the public than they did 50 or 100 years ago (see Evans \& Quigley, 2003). Consistent with this change in social preferences, tenure review has resulted in hundreds of thousands of hectares of land formerly leased to farmers being added to the conservation estate. In addition, the transfer of some land to freehold tenure is socially beneficial because this more easily facilitates multiple use of land, and alternative uses of land, than did the pastoral leases. Payments of cash and freehold land represent the necessary costs associated with the creation of improved conservation and land use outcomes in the high country as they are valued by contemporary society.

The analysis in this paper suggests that Brower's dissent from the outcomes of the tenure review process rests on three factors: (i) an interpretation of the property rights of lessees that is at variance with the interpretation of those property rights normally adopted by valuers and economists; (ii) claims about the process of establishing values in tenure review which are inconsistent with the information that is publicly available; and (iii) a regression analysis which has an independent variable with no clear economic interpretation, and therefore produces output which makes no contribution to our understanding of tenure review. 


\section{References}

Armstrong, D., R. Engelbrecht \& R. Jefferies (2005) Interim Report: high country pastoral leases review, Wellington: Land Information New Zealand

Boyle, G., G. Guthrie \& N. Quigley (2008) 'Determining the rental rate on commercial real estate leases', unpublished manuscript, Victoria University of Wellington

Brower, A. (2007) 'Whither the Crown's interest in South Island high country land reform', Policy Quarterly, 3 (4) pp.30-8

Brower, A., A. Monks \& P. Meguire (2007) 'Closing the deal: principals, agents and sub-agents in New Zealand land reform', unpublished manuscript

Evans L. \& N. Quigley (2003) 'Pastoral leases', Competition and Regulation Times, 6, December, Wellington: NZICSR

\section{Neil Quigley is Professor of}

Economics and Deputy Vice-

Chancellor (Research) at Victoria

University of Wellington. His research

covers a wide range of topics in

applied microeconomics, including competition, regulation and property rights. In addition he has appeared as an expert witness for both lessees and lessors in a number of arbitrations relating to valuations and rental rates in perpetually renewable real estate leases

\section{REBALANCING THE CONSTITUTION: The Challenge of Government Law-Making Under MMP}

\section{An Institute of Policy Studies publication by Ryan} Malone

In 1993, a majority of New Zealand voters rejected the longstanding first-past-the-post electoral system in favour of the mixed member proportional (MMP) system - a form of proportional representation never before used in New Zealand

With more than a decade having passed since the first MMP election in 1996, this book examines the impact of proportional representation on New Zealand's constitution. It considers how the constraints of multi-party politics have curtailed executive power and strengthened the role of parliament. To understand the extent of this change, Ryan Malone explores the difficulties that coalition and minority governments have in controlling government bills compared with single-party governments under first-past-the-post. He pays particular attention to the legislative implications of the government formation process, inter-party competition over policy, the growing independence of select committees, and the general slowing of the parliamentary legislative process.

This highly readable book provides numerous insights into the relationship between the executive and legislative branches of government. It will appeal to the specialised reader, as well as to people with a general interest in politics and parliamentary law-making.

Ryan Malone was awarded his PhD in Law at Victoria University of Wellington in 2007. This book is based on this doctoral research.

Published - February 2008

Format - B5 Paperback, pp 259

ISBN - 1-877347-20-5

Price - \$35.00 (including P\&P within New Zealand)

To have a copy of Rebalancing the Constitution by Ryan Malone and an invoice sent to you, please email, phone, fax or mail your order to:

Institute of Policy Studies

Victoria University of Wellington

Email ipos@vuw.ac.nz

Telephone +64 44635307

Fax +6444637413

P0 Box 600, Wellington, New Zealand 